\title{
Influence of Water and Nitrogen Stress on Stem Sap Flow of Tomato Grown in a Solar Greenhouse
}

\author{
Rangjian Qiu \\ Jiangsu Provincial Key Laboratory of Agricultural Meteorology, College of Applied Meteorology, \\ Nanjing University of Information Science and Technology, Nanjing, 210044, China; and the Center \\ for Agricultural Water Research in China, China Agricultural University, Beijing, 100083, China \\ Taisheng Du', Shaozhong Kang, and Renqiang Chen \\ Center for Agricultural Water Research in China, China Agricultural University, 17 Qinghua East \\ Road, Haidian District, Beijing, 100083, China \\ Laosheng Wu \\ Department of Environmental Sciences, University of California, Riverside, CA 92521
}

\begin{abstract}
AdDitional INDEX words. meteorological factors, stomatal conductance, transpiration, nighttime sap flow
Abstract. Accurate measurement of crop water use under different water and nitrogen (N) conditions is of great importance for irrigation scheduling and $\mathrm{N}$ management. This research investigated the effect of water and $\mathrm{N}$ status on stem sap flow of tomato (Solanum lycopersicum) grown in an unheated solar greenhouse in northwest China. A water experiment included sufficient water supply $\left(T_{1}\right)$ based on in situ water content measurement, two-thirds $T_{1}$ $\left(T_{2}\right)$ and half $T_{1}\left(T_{3}\right)$ under a typical $N$ application rate $\left(N_{1}\right)$; i.e., $57.4 \mathrm{~g} \cdot \mathrm{m}^{-2} \mathrm{~N}$. The $\mathrm{N}$ experiment included $\mathrm{N}_{1}$, twothirds $N_{1}\left(N_{2}\right)$, and half $N_{1}\left(N_{3}\right)$ under $T_{2}$ irrigation. Results showed that deficit water supply reduced the stem sap flow by $22.1 \%$ and $42.8 \%$ in $T_{2}$ and $T_{3}$, respectively, compared with $T_{1}$. The average daily stem sap flow between $N_{1}$ and $N_{2}$ was similar, and both were higher than that of $N_{3}$. Significant differences between $N_{1}$ or $N_{2}$ and $N_{3}$ were only observed on four dates (totally 34 days). Nighttime stem sap flow accounted for $6.0 \%$ to $6.9 \%$ of the daily value for the water treatments and $5.7 \%$ to $8.5 \%$ of the daily value for the $\mathrm{N}$ treatments. No significant differences for nighttime stem sap flow were found among water and $\mathrm{N}$ treatments. The daily stem sap flow was significantly and positively correlated with solar radiation, air temperature, vapor pressure deficit, and reference evapotranspiration under the water and $\mathbf{N}$ experiments. The slopes of the regression equations between the daily stem sap flow and these parameters were lower when soil water availability was limited, whereas the slopes of the regressions had no significant differences among $\mathbf{N}$ treatments. A parabolic relationship between the ratio of the daily stem sap flow of water deficit treatments to that of $T_{1}$ and soil relative extractable water content was observed.
\end{abstract}

The unheated solar greenhouse industry has been expanding rapidly and becoming increasingly important for local economies in the arid region of northwest China in recent years, because the region has abundant light resources but limited precipitation (rain and snow) in winter. However, shortage of water resources and $\mathrm{N}$ stress (too little or too much) often affects the sustainable production of greenhouse crops in the region. Water and $\mathrm{N}$ stresses not only affect water uptake and nutrient assimilation of plants, but also influence stomatal response and drought resistance ability (Chapin et al., 1988; Claussen, 2002; Davies and Zhang, 1991). Thus, accurate measurement of crop water use under different water and $\mathrm{N}$ conditions can provide information for precision irrigation and $\mathrm{N}$ management.

Water deficit has an adverse effect on transpiration, which has been confirmed in sap flow studies for many woody tree

Received for publication 29 Sept. 2014. Accepted for publication 1 Dec. 2014 We gratefully acknowledge the financial support by the China Scholarship Council for the senior author to carry out the research at the University of California, Riverside. We are grateful for the research grants from the National Natural Science Foundation of China $(51222905,51321001)$, the National High-Tech 863 Project of China (2011AA100502), the Discipline Innovative Engineering Plan (111 Program, B14002), the Program of New Century Excellent Talents in University, Ministry of Education (NCET-11-0479), and the Startup Foundation for Introducing Talent of NUIST (S8113113001).

${ }^{1}$ Corresponding author. E-mail: dutaisheng@cau.edu.cn. species such as olive [Olea europaea (Fernández et al., 2001; Tognetti et al., 2004)], pear-jujube [Ziziphus jujuba (Ma et al., 2007)], lemon [Citrus $\times$ limon (Ortuño et al., 2005, 2006)], and peach [Prunus persica (Gong et al., 2001)]. A limited number of studies have been conducted to test the effect of water deficit on sap flow of tomato plants. Yang et al. (2012) showed that sap flow of tomato was seriously reduced by a severe water deficit treatment at the flowering and fruit set stages, and the diurnal variation of tomato sap flow in sunny days followed a bimodal curve under normal irrigation and mild water deficit treatments. A reduction in sap flow that was observed for tomato 2 or $3 \mathrm{~d}$ after water stress was imposed became more significant over time (Grey, 2010; Vermeulen et al., 2007).

Contradictory results concerning the effect of $\mathrm{N}$ on sap flow have been observed for different plant species, and it is likely that soil water status may interactively influence the effect of $\mathrm{N}$ on sap flow. Zhang et al. (2009) found that stem sap flow of peach seedling was higher at the higher $\mathrm{N}$ application rate under higher water application treatment, but lower stem sap flow was observed at the higher $\mathrm{N}$ application rate if plants suffered water deficit. In a shrub (Ligustrum ovalifolium), the cumulative xylem sap flow with low $\mathrm{N}$ application rate was higher than those with high $\mathrm{N}$ application rate (Guérin et al., 2007). Guak et al. (2003) observed that there was no significant effect of $\mathrm{N}$ treatment on daily sap flow in apple (Malus $\times$ domestica) trees when soil water content was sufficient. 
Therefore, there has been a limited number of studies conducted to assess the effect of water and $\mathrm{N}$ deficit on plant sap flow. No study has been conducted to assess the effect of water and $\mathrm{N}$ treatments on stem sap flow of greenhouse-grown tomatoes in an arid region such as northwest China. In addition, nighttime transpiration, which accounted for a significant proportion of the total daily transpiration and lowered the crop water productivity, has been observed in many $\mathrm{C}_{3}$ and $\mathrm{C}_{4}$ species (Caird et al., 2007a, 2007b; Medrano et al., 2005; Snyder et al., 2003; Yoo et al., 2009). However, little information was available for tomato under different water and $\mathrm{N}$ treatments. The objectives of this study are to 1) evaluate the response of stem sap flow of tomato to water deficit in a solar greenhouse; 2) assess the effect of $\mathrm{N}$ stress (exceed or deficit) on stem sap flow; and 3) analyze the relationship between stem sap flow and meteorological parameters under different water and $\mathrm{N}$ treatments.
Table 1. Amounts of irrigation and times in the 2010-11 season at different growth stages of tomato for different water treatments. ${ }^{\mathrm{z}}$

\begin{tabular}{lcccc}
\hline & \multicolumn{4}{c}{ Irrigation [mm (no.)] } \\
\cline { 2 - 5 } Treatment & $\begin{array}{c}\text { Seedling } \\
\text { stage }\end{array}$ & $\begin{array}{c}\text { Flowering and } \\
\text { fruit set stage }\end{array}$ & $\begin{array}{c}\text { Fruit set and } \\
\text { harvest stage }\end{array}$ & $\begin{array}{c}\text { Entire } \\
\text { season }\end{array}$ \\
\hline $\mathrm{T}_{1}$ & $32.0(2)$ & $83.9(3)$ & $279.5(10)$ & $395.4(15)$ \\
$\mathrm{T}_{2}$ & $32.0(2)$ & $83.9(3)$ & $186.3(10)$ & $302.2(15)$ \\
$\mathrm{T}_{3}$ & $32.0(2)$ & $83.9(3)$ & $139.8(10)$ & $255.6(15)$
\end{tabular}

${ }^{z}$ The numbers in parentheses indicate the total times of irrigations for the respective growth stages. $\mathrm{T}_{1}, \mathrm{~T}_{2}$, and $\mathrm{T}_{3}$ are sufficient water supply, two-thirds $\mathrm{T}_{1}$, and half $\mathrm{T}_{1}$, respectively, under a typical nitrogen $(\mathrm{N})$ application rate (i.e., $57.4 \mathrm{~g} \cdot \mathrm{m}^{-2} \mathrm{~N}$ ). Tomato growth stages in the $2010-11$ season can be divided as follows: seedling stage (26 Dec. 2010 to 22 Jan. 2011, 27 d), flowering and fruit set stages (23 Jan. to 24 Mar., 61 d), and fruit set and harvest stage (25 Mar. to 26 June, 94 d).

Table 2. Nitrogen application rates in the 2012 season at different growth stages of tomato for different nitrogen $(\mathrm{N})$ treatments. $^{\mathrm{z}}$

\begin{tabular}{lcccr}
\hline & \multicolumn{4}{c}{$\mathrm{N}$ application $\left[\mathrm{g} \cdot \mathrm{m}^{-2}\right.$ (no.) } \\
\cline { 2 - 5 } Treatment & $\begin{array}{c}\text { Seedling } \\
\text { stage }\end{array}$ & $\begin{array}{c}\text { Flowering and } \\
\text { fruit set stage }\end{array}$ & $\begin{array}{c}\text { Fruit set and } \\
\text { harvest stage }\end{array}$ & $\begin{array}{c}\text { Entire } \\
\text { season }\end{array}$ \\
\hline $\mathrm{N}_{1}$ & 0.0 & $28.2(3)$ & $29.2(3)$ & $57.4(6)$ \\
$\mathrm{N}_{2}$ & 0.0 & $18.8(3)$ & $19.5(3)$ & $38.3(6)$ \\
$\mathrm{N}_{3}$ & 0.0 & $14.1(3)$ & $14.6(3)$ & $28.7(6)$ \\
\hline
\end{tabular}

${ }^{z}$ The numbers in the brackets indicate the total times of $\mathrm{N}$ applications for the respective growth stages. $\mathrm{N}_{1}, \mathrm{~N}_{2}$, and $\mathrm{N}_{3}$ are typical $\mathrm{N}$ application rate (i.e., $57.4 \mathrm{~g} \cdot \mathrm{m}^{-2} \mathrm{~N}$ ), two-thirds $\mathrm{N}_{1}$, and half $\mathrm{N}_{1}$, respectively, under two-thirds sufficient water supply. Tomato growth stages in the 2012 season can be divided as follows: seedling stage (28 Feb. 2012 to 19 Mar., 20 d), flowering and fruit set stages (20 Mar. to 2 May, 44 d), and fruit set and harvest stage (3 May to 5 July, 64 d).

\section{Materials and Methods}

ENVIRONMENTAL CONDitions AND PLANT Materials. The water and $\mathrm{N}$ treatment experiments were conducted at Shiyanghe Experimental Station for Water-Saving in Agriculture and Ecology of China Agricultural University, located in Wuwei City, Gansu Province of northwest China (lat. $37^{\circ} 52^{\prime} \mathrm{N}$, long. $102^{\circ} 51^{\prime} \mathrm{E}, 1581 \mathrm{~m}$ altitude). It is in a typical continental, temperate climate zone. The annual mean temperature is $8.8^{\circ} \mathrm{C}$ and the mean annual frost-free period is $150 \mathrm{~d}$. Solar radiation is abundant in the region with annual mean sunshine of $3000 \mathrm{~h}$. The mean annual precipitation in the region is only $164.4 \mathrm{~mm}$, whereas the mean annual pan evaporation is $2000 \mathrm{~mm}$. The groundwater table is below $25 \mathrm{~m}$.

The solar greenhouse was made of a steel frame covered with a $0.2-\mathrm{mm}$-thick thermal polyethylene sheet. Because the greenhouse had no heat system, straw mats were spread over the roof of the thermal polyethylene sheet during the winter months to maintain the interior temperature at night. The interior temperature during daytime was controlled by a narrow ventilation system on the roof with the maximum opening of $0.5 \mathrm{~m}$. More details of the solar greenhouse construction were described by Qiu et al. (2011). The soil is a desert sandy loam (Siltigic-Orthic Anthrosols) with a mean bulk density of $1.46 \mathrm{~g} \cdot \mathrm{cm}^{-3}$, field water capacity $\left(\theta_{\mathrm{F}}\right)$ of $0.36\left(\mathrm{~cm}^{3} \cdot \mathrm{cm}^{-3}\right)$ and wilting point $\left(\theta_{\mathrm{w}}\right)$ of $0.10\left(\mathrm{~cm}^{3} \cdot \mathrm{cm}^{-3}\right)$. Electrical conductivity of the irrigation water was $0.52 \mathrm{dS} \cdot \mathrm{m}^{-1}$.

Indeterminate tomato (cv. Zhongyan and Oyadi, respectively) plants were transplanted on 26 Dec. 2010 and 28 Feb. 2012, respectively, for the $2010-11$ and 2012 seasons. Two rows of seedlings were evenly transplanted along the edge of each furrow with row spacing across the furrow of $0.40 \mathrm{~m}$
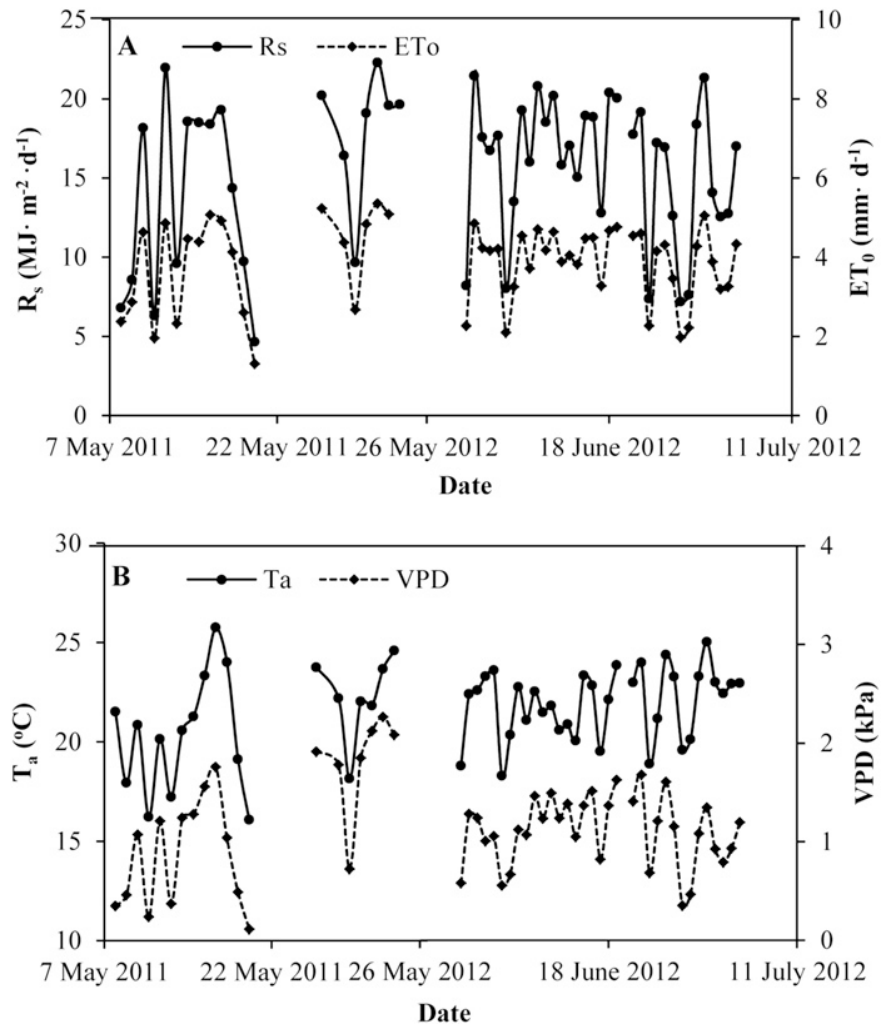

Fig. 1. Variation of daily solar radiation $\left(\mathrm{R}_{\mathrm{s}}\right)$, reference evapotranspiration $\left(\mathrm{ET}_{0}\right)$, air temperature $\left(\mathrm{T}_{\mathrm{a}}\right)$, and vapor pressure deficit (VPD) during the sap flow measurement periods of tomato in the water and nitrogen $(\mathrm{N})$ experiments. 
and interplant spacing of $0.40 \mathrm{~m}$. The widths of furrow and adjacent bed were 0.40 and $0.75 \mathrm{~m}$, respectively. The plant rows were oriented in a north-south direction for better interception of sunlight. At 3 to $10 \mathrm{~d}$ after transplanting (DAT), the soil surface was covered with clear, $5-\mu \mathrm{m}$-thick polyethylene film to reduce soil evaporation and to increase the soil temperature. On some sunny days during June 2012, the greenhouse was partially shaded around noon with straw mats to avoid high interior temperature.

EXPERIMENT DESIGN. The water treatment experiment was conducted from Dec. 2010 to June 2011. The water treatments included $\mathrm{T}_{1}, \mathrm{~T}_{2}$, and $\mathrm{T}_{3}$ under local farmers' $\mathrm{N}_{1}$; i.e., $57.4 \mathrm{~g} \cdot \mathrm{m}^{-2} \mathrm{~N}$. The water deficit treatments were imposed after 89 DAT (at fruit set and harvest stages), when $\mathrm{T}_{2}$ and $\mathrm{T}_{3}$ received two-thirds and half of the full irrigation amount, respectively, at each irrigation event (Table 1). To keep the seedlings alive and enhance growth, two irrigations with the same amount of water $(16.0 \mathrm{~mm})$ were applied at transplanting and 15 DAT for all the water treatments. After $15 \mathrm{DAT}$, tomato plants were irrigated to $90 \% \theta_{\mathrm{F}}$ when average soil water content in the main root zone $\left(Z_{\mathrm{r}}=50 \mathrm{~cm}\right)$ in $\mathrm{T}_{1}$ was depleted to $75 \% \pm 2 \%$ of $\theta_{\mathrm{F}}$. For each irrigation event, the amount of water applied, D (mm), was calculated by:

$$
\mathrm{D}=10 \times\left(0.9 \theta_{\mathrm{F}}-\theta_{\mathrm{i}}\right) \times \mathrm{Z}_{\mathrm{r}}
$$

where $\theta_{\mathrm{i}}$ is the actual average soil moisture content in the main root zone before irrigation $\left(\mathrm{cm}^{3} \cdot \mathrm{cm}^{-3}\right)$.

Irrigation was applied on the same day for all treatments. The irrigation water was applied to the dead-end furrow side and no tail flow was allowed. The irrigation amount was recorded for each plot by a water meter at the end of the irrigation pipe. To prevent lateral movement of soil water to neighboring plots, a plastic sheet was embedded in the soil to a depth of $0.6 \mathrm{~m}$ around each plot.

The $\mathrm{N}$ treatment experiment was conducted from Feb. to July 2012. Treatments included $\mathrm{N}_{1}, \mathrm{~N}_{2}$, and $\mathrm{N}_{3}$ under $\mathrm{T}_{2}$ irrigation. Table 2 shows the $\mathrm{N}$ application rates for each treatment at different growth stages. For the 2012 season, the two irrigation events with the same water amount of $27.9 \mathrm{~mm}$ were applied at transplanting and 12 DAT. After 12 DAT, all $\mathrm{N}$ treatments received two-thirds of sufficient water amount.
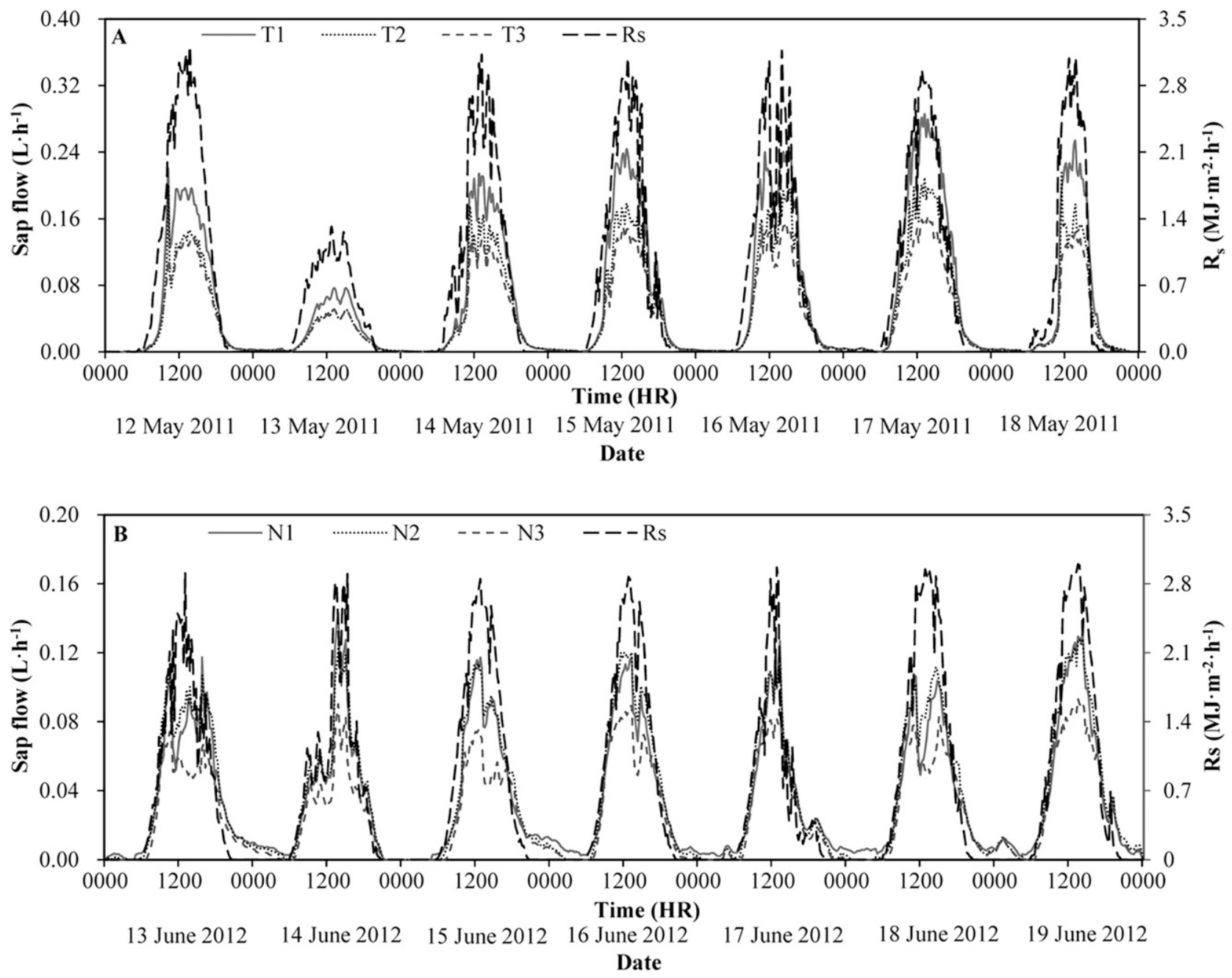

Fig. 2. The diurnal variation of stem sap flow of tomato for selected dates under different $(\mathbf{A})$ water and $(\mathbf{B})$ nitrogen $(\mathrm{N})$ treatments $\left(\mathrm{n}=\right.$ two replications). $\mathrm{T}_{1}, \mathrm{~T}_{2}$, and $\mathrm{T}_{3}$ are sufficient water supply, two-thirds $\mathrm{T}_{1}$, and half $\mathrm{T}_{1}$, respectively, under a typical $\mathrm{N}$ application rate $\left(\mathrm{N}_{1}\right)$; i.e., $57.4 \mathrm{~g} \cdot \mathrm{m}^{-2} \mathrm{~N} . \mathrm{N}_{2}$ and $\mathrm{N}_{3}$ are two-thirds $\mathrm{N}_{1}$ and half $\mathrm{N}_{1}$, respectively, under $\mathrm{T}_{2} ; \mathrm{R}_{\mathrm{s}}=$ solar radiation. 
The fertilizer was dissolved in water before each irrigation event and supplied with irrigation water. To determine application timing, water treatment $T_{1}$ was also set up in the 2012 season.

The area of each plot was $19.32 \mathrm{~m}^{2}(5.6 \mathrm{~m}$ long $\times 3.45 \mathrm{~m}$ wide), consisting of three furrows and three beds with 84 tomato plants. The water treatments in the 2010-11 season and $\mathrm{N}$ treatments in the 2012 season were replicated three times, respectively, and the plots were a randomized complete block design.

Throughout each crop season, other management practices such as pollination, pruning branch stem, and pest control were the same for all treatments. In the 2012 season, all the $\mathrm{N}$ treatments received phosphorus and potassium at rates of 17.9 and $12.8 \mathrm{~g} \cdot \mathrm{m}^{-2}$, respectively, and they were supplied with irrigation water.

Measurements AND methods. Soil water content was measured using a portable capacitance sensor system (Diviner 2000; Sentek, Stepney, Australia). Two polyvinyl chloride access tubes were installed with one in the center of the bed and the other in the middle furrow for each water treatment plot in the 2010-11 season and for $T_{1}$ in the 2012 season. Measurements were made at $0.1-\mathrm{m}$ intervals with maximal soil depth of $1.0 \mathrm{~m}$ every 3 to $7 \mathrm{~d}$ as well as before and after irrigation. Soil relative extractable water content (REW) was defined as follows:

$$
\mathrm{REW}=\frac{\theta-\theta_{\mathrm{w}}}{\theta_{\mathrm{F}}-\theta_{\mathrm{w}}}
$$

where $\theta$ is the average soil moisture content in the 0 - to $50-\mathrm{cm}$ soil layer $\left(\mathrm{cm}^{3} \cdot \mathrm{cm}^{-3}\right)$.

Meteorological data were measured with an automatic weather station (Hobo; Onset Computer, Pocasset, MA) located in the center of the greenhouse. Solar radiation $\left(\mathrm{R}_{\mathrm{s}}\right)$, air temperature $\left(\mathrm{T}_{\mathrm{a}}\right)$, and relative humidity $(\mathrm{RH})$ were measured every $5 \mathrm{~s}$, and 15-min averages were calculated and stored in a data logger.

As a result of low air speed in the greenhouse, the FAO 56 Penman-Monteith method with a fixed aerodynamic resistance of $295 \mathrm{~s} \cdot \mathrm{m}^{-1}$ (Fernández et al., 2010, 2011) was used to calculate the daily reference evapotranspiration. The calculated equation was described by Qiu et al. (2013).

Stem sap flow was measured by a Flow 32-1K system (Dynamax, Houston, TX). As a result of the limitation of the sensors (eight sensors in one Flow 32-1K system), only two tomato plants were randomly chosen at each treatment to monitor sap flow from 8 to 20 May and 27 May to 2 June 2011 for the water treatments and from 31 May to 5 July 2012 except for 20 June 2012 for the $\mathrm{N}$ treatments. Gauge output was monitored every $5 \mathrm{~s}$ and recorded as 15-min averages with a data logger (CR1000; Campbell Scientific, Logan, UT). Further details on the methods, theoretical background, and installation procedure were described in Trambouze and Voltz (2001).

Diurnal variation of leaf stomatal conductance $\left(g_{\mathrm{S}}\right)$ was measured by a leaf porometer (SC-1; Decagon Devices, Pullman, WA) for the water treatments and a portable photosynthesis system (LI-6400; LI-COR, Lincoln, NE) for the N treatments. Three to five fully grown leaves of the plants that were used for measuring sap flow at each treatment were selected for the continuous measurement of leaf $g_{\mathrm{S}}$. Measurements were taken every $2 \mathrm{~h}$ from 0900 to $1900 \mathrm{HR}$ on 23 Apr. 2011 (at fruit set and harvest stages) for the water treatments and from 0800 to $2000 \mathrm{HR}$ on 29 May 2012 (at fruit set and harvest stages) for the $\mathrm{N}$ treatments.

Leaf chlorophyll content was measured using a chlorophyll meter (SPAD 502; Minolta Camera, Osaka, Japan) every 3 to $13 \mathrm{~d}$ during sap flow measurement periods. The SPAD 502 has a $0.06-\mathrm{cm}^{2}$ measurement area and calculates an index in SPAD units (dimensionless) based on absorbance at 650 and $940 \mathrm{~nm}$. The accuracy of the SPAD 502 is \pm 1.0 SPAD units. In each $\mathrm{N}$ treatment, SPAD values of plants that were used for measuring sap flow on each leaflet of the leaf closest to each specific cluster were measured. Each SPAD value was the mean of the measurements in all leaflets of each plant.

Leaf area index (LAI) for each $\mathrm{N}$ plot was measured every 7 to $24 \mathrm{~d}$ for four numbers of measurements using a nondestructive canopy analysis system (SunScan; Delta-T Devices,

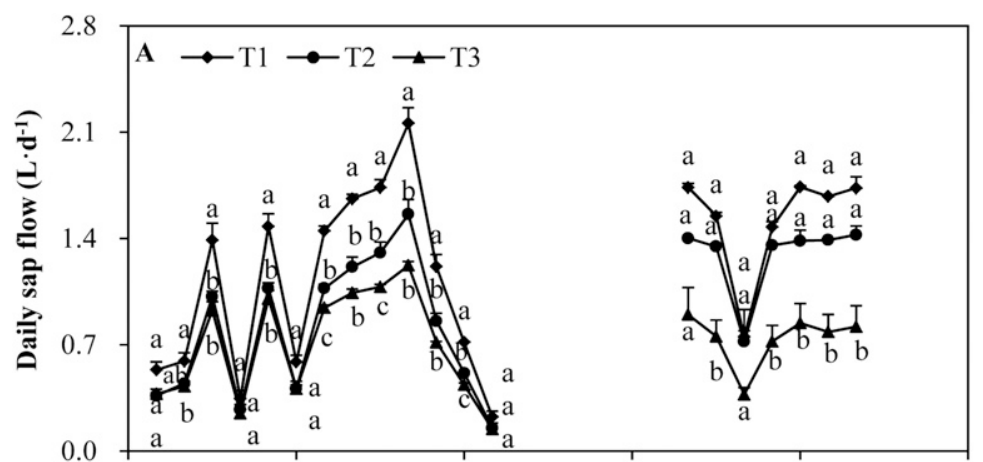

7 May 2011 13 May 2011 19 May 201125 May 201131 May 20116 June 2011

Date

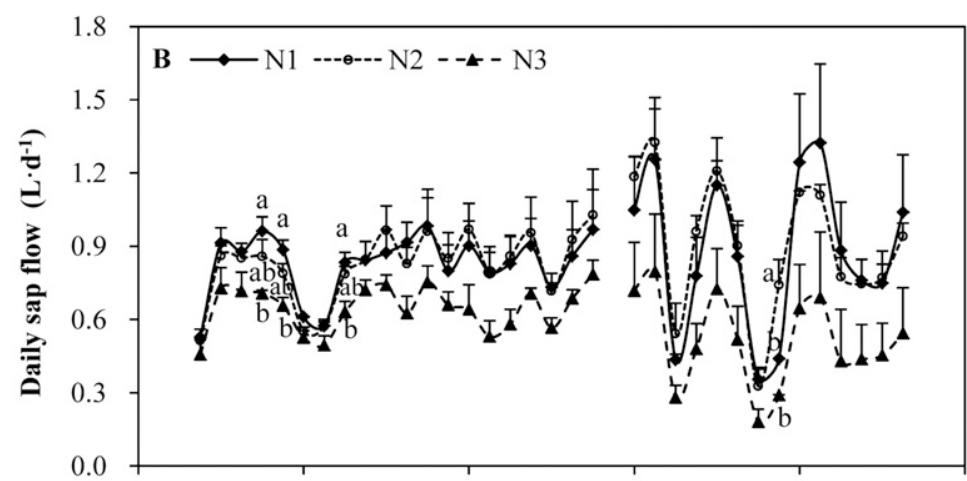

28 May 20125 June 201213 June 201221 June 2012 29 June 20127 July 2012

Date

Fig. 3. Variation of daily stem sap flow of tomato under different (A) water and (B) nitrogen (N) treatments throughout the study period. Error bars indicate SE $(\mathrm{n}=$ two replications). Mean values at each time point followed by different letters $(\mathrm{a}-\mathrm{c})$ are significantly different at the $P_{0.05}$ level. For the $\mathrm{N}$ treatments, the dates with no significantly different were not marked. $\mathrm{T}_{1}, \mathrm{~T}_{2}$, and $\mathrm{T}_{3}$ are sufficient water supply, two-thirds $\mathrm{T}_{1}$, and half $\mathrm{T}_{1}$, respectively, under a typical $\mathrm{N}$ application rate $\left(\mathrm{N}_{1}\right)$; i.e., $57.4 \mathrm{~g} \cdot \mathrm{m}^{-2} \mathrm{~N}$. $\mathrm{N}_{2}$ and $\mathrm{N}_{3}$ are two-thirds $\mathrm{N}_{1}$ and half $\mathrm{N}_{1}$, respectively, under $\mathrm{T}_{2}$. 
Cambridge, U.K.). The system consists of 64 photosynthetically active radiation $(P A R)$ sensors embedded in a 1-m-long probe, which uses field measurements of $P A R$ in crop canopies to measure LAI.

Data analysis and statistics. Mixed model analysis of variance was performed with SPSS (Version 21.0; IBM Corp., Armonk, NY) to determine the effects of water or $\mathrm{N}$ stress on stem sap flow, leaf $g_{\mathrm{S}}$, soil water content, leaf SPAD, LAI, and slopes between daily sap flow and climate parameters.

\section{Results}

\section{Microclimate conditions in solar greenhouse}

Figure 1 shows the variation of daily microclimate conditions during the sap flow measurement periods. For the water experiment period, the daily values of $\mathrm{R}_{\mathrm{s}}, \mathrm{T}_{\mathrm{a}}$, vapor pressure deficit (VPD), and reference evapotranspiration $\left(\mathrm{ET}_{0}\right)$ ranged from 4.6 to $22.3 \mathrm{MJ} \cdot \mathrm{m}^{-2} \cdot \mathrm{d}^{-1}, 16.1$ to $25.8^{\circ} \mathrm{C}, 0.12$ to $2.25 \mathrm{kPa}$, and 1.3 to $4.9 \mathrm{~mm} \cdot \mathrm{d}^{-1}$, respectively. For the $\mathrm{N}$ experiment period, the daily values of $\mathrm{R}_{\mathrm{s}}, \mathrm{T}_{\mathrm{a}}, \mathrm{VPD}$, and $\mathrm{ET}_{0}$ were 7.2 to $21.5 \mathrm{MJ} \cdot \mathrm{m}^{-2} \cdot \mathrm{d}^{-1}, 18.3$ to $25.1^{\circ} \mathrm{C}, 0.35$ to $1.68 \mathrm{kPa}$, and 1.9 to $4.9 \mathrm{~mm} \cdot \mathrm{d}^{-1}$, respectively.

\section{Dynamics of stem sap flow under different water and nitrogen treatments}

Hourly SCALE. Figure 2 shows the diurnal variation of mean stem sap flow of two replications for selected dates under different water and $\mathrm{N}$ treatments. For all water treatments, the diurnal patterns of stem sap flow on sunny days showed a steep increase with the increase in the morning in solar radiation, leading to a maximum rate near noon (when solar radiation was at its maximum) followed by a sustained gradual decrease until late in the afternoon (Fig. 2A). The peak stem sap flow in the daytime was highest in $\mathrm{T}_{1}$, followed by $\mathrm{T}_{2}$ and $\mathrm{T}_{3}$; and the trend was the same at night when there was stem sap flow although there was no solar radiation. Stem sap flow was lower on cloudy and rainy days when solar radiation was lower. Compared with a sunny day (12 May 2011), the maximum solar radiation was decreased by $59.1 \%$ on 13 May 2011, when the maximum sap flow decreased by $65.2 \%, 74.4 \%$, and $63.2 \%$, respectively, for the three different water treatments. The peak sap flow of $\mathrm{T}_{2}$ was close to that of $\mathrm{T}_{3}$ on cloudy days when solar radiation was low.

The diurnal pattern of stem sap flow for the $\mathrm{N}$ treatments was similar to that for the water treatments (Fig. 2B). The maximum stem sap flow of $\mathrm{N}_{1}$ was close to that of $\mathrm{N}_{2}$, but both were higher than $\mathrm{N}_{3}$. Taking a sunny day (19 June 2012) as an example, the peak stem sap flow was 0.132 and $0.128 \mathrm{~L} \cdot \mathrm{h}^{-1}$, respectively, for $\mathrm{N}_{1}$ and $\mathrm{N}_{2}$, which was $\approx 30 \%$ higher than that of $\mathrm{N}_{3}$.

When the greenhouse was partially overshadowed around noon (e.g., 18 June 2012) with straw mats to avoid high interior temperature, the variation of stem sap flow with time did not correspond to that of solar radiation (Fig. 2B).

DaILy SCALE. Figure 3A shows the differences in daily stem sap flow relative to different water treatments. Water deficit decreased daily stem sap flow of tomato grown in the greenhouse. Compared with $\mathrm{T}_{1}$, the average daily stem sap flow was $22.1 \%$ and $42.8 \%$, respectively, lower for $\mathrm{T}_{2}$ and $\mathrm{T}_{3}$ during the measurement period. The maximum daily stem sap flow was $2.16,1.56$, and $1.22 \mathrm{~L} \cdot \mathrm{d}^{-1}$, respectively, for $\mathrm{T}_{1}, \mathrm{~T}_{2}$, and $\mathrm{T}_{3}$ on 17 May 2011 (sunny day), and the minimum was 0.23 , 0.15 , and $0.14 \mathrm{~L} \cdot \mathrm{d}^{-1}$, respectively, on 20 May 2011 (cloudy day). Climate conditions affected the difference of stem sap flow in different water treatments. On sunny days, there were big differences in stem sap flow among the water treatments. However, the stem sap flow on cloudy days (except for 29 May 2011) was similar between $T_{2}$ and $T_{3}$. The cumulative nighttime stem sap flow during the measurement period $(20 \mathrm{~d})$ was $1.48,1.33$, and $0.90 \mathrm{~L}$, respectively, for $\mathrm{T}_{1}, \mathrm{~T}_{2}$, and $\mathrm{T}_{3}$, which accounted for $6.0 \%$ to $6.9 \%$ of the total stem sap flow. Significant $(P<0.05)$ linear relationships between nighttime sap flow and nighttime VPD were observed under different water treatments (Fig. 4A), but no significant differences were found for the slopes of the regression equations. The daily stem sap flow (SF) increased linearly with REW (SF $=2.56 \mathrm{REW}$ $\left.-0.13 ; R^{2}=0.79\right)$. During the water deficit period, the ratio of daily stem sap flow of water deficit treatments $\left(T_{2}\right.$ and $\left.T_{3}\right)$ to that of non-deficit water treatment $\left(T_{1}\right)$ was related to REW. The relative daily stem sap flow $\left(\mathrm{SF}_{\mathrm{Ti}} / \mathrm{SF}_{\mathrm{T} 1}\right)$ increased rapidly as REW increased. When REW reached a threshold of 0.57 , the $\mathrm{SF}_{\mathrm{Ti}} / \mathrm{SF}_{\mathrm{T} 1}$ increased slowly $\left(\mathrm{SF}_{\mathrm{i}} / \mathrm{SF}_{\mathrm{T} 1}=-7.3 \mathrm{REW}^{2}+8.3 \mathrm{REW}\right.$ $-1.6, R^{2}=0.56$, where $\mathrm{SF}_{\mathrm{i}}$ is daily sap flow for $\mathrm{T}_{2}$ and $\mathrm{T}_{3}$ and $\mathrm{SF}_{\mathrm{T} 1}$ is the daily stem sap flow for $\mathrm{T}_{1}$ ).

The daily stem sap flow varied from 0.35 to $1.32,0.33$ to 1.32 , and 0.18 to $0.80 \mathrm{~L} \cdot \mathrm{d}^{-1}$, respectively, for $\mathrm{N}_{1}, \mathrm{~N}_{2}$, and $\mathrm{N}_{3}$. The daily stem sap flow of $\mathrm{N}_{1}$ was similar to that of $\mathrm{N}_{2}$, but both were higher than that of $\mathrm{N}_{3}$ (Fig. 3B). Significant differences between $\mathrm{N}_{1}$ or $\mathrm{N}_{2}$ and $\mathrm{N}_{3}$ were only observed on 3 June, 4 June, 7 June, and 28 June 2012. The cumulative nighttime stem sap flow during the measurement period ( $34 \mathrm{~d}$ ) was 2.46, 2.03, and $1.15 \mathrm{~L}$, respectively, for $\mathrm{N}_{1}, \mathrm{~N}_{2}$, and $\mathrm{N}_{3}$, which accounted for $5.7 \%$ to $8.5 \%$ of the total daily stem sap flow. A significant
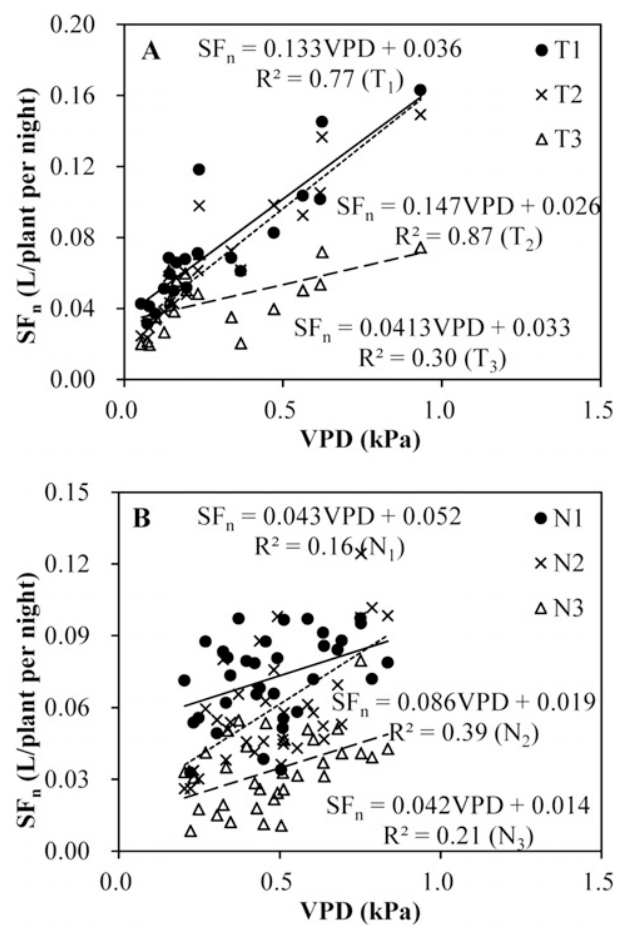

Fig. 4. Relationship between nighttime sap flow $\left(\mathrm{SF}_{\mathrm{n}}\right)$ of tomato and vapor pressure deficit (VPD) under different $(\mathbf{A})$ water and (B) nitrogen $(\mathrm{N})$ treatments. $T_{1}, T_{2}$, and $T_{3}$ are sufficient water supply, two-thirds $T_{1}$, and half $\mathrm{T}_{1}$, respectively, under a typical $\mathrm{N}$ application rate $\left(\mathrm{N}_{1}\right)$; i.e., $57.4 \mathrm{~g} \cdot \mathrm{m}^{-2} \mathrm{~N} . \mathrm{N}_{2}$ and $\mathrm{N}_{3}$ are two-thirds $\mathrm{N}_{1}$ and half $\mathrm{N}_{1}$, respectively, under $\mathrm{T}_{2}$. 
$(P<0.05)$ linear relationship was also found between nighttime sap flow and nighttime VPD under different $\mathrm{N}$ treatments (Fig. 4B), but no significant differences were found for the slopes of the regression equations. During the period of $\mathrm{N}$ stress in this study, the relative daily stem sap flow rate $\left[\mathrm{SF}_{\mathrm{i}} / \mathrm{SF}_{(\mathrm{N} 1+\mathrm{N} 2) / 2}\right]$ increased linearly as the relative leaf $\mathrm{SPAD}\left[\mathrm{SPAD}_{\mathrm{i}} /\right.$ $\left.\mathrm{SAPD}_{(\mathrm{N} 1+\mathrm{N} 2) / 2}\right]$ increased from 0.90 to $0.96\left[\mathrm{SF}_{\mathrm{i}} / \mathrm{SF}_{(\mathrm{N} 1+\mathrm{N} 2) / 2}=\right.$ $3.96\left(\mathrm{SPAD}_{\mathrm{i}} / \mathrm{SPAD}_{(\mathrm{N} 1+\mathrm{N} 2) / 2}\right)-2.91, R^{2}=0.86$, where $\mathrm{SF}_{\mathrm{i}}$ is stem sap flow for $\mathrm{N}_{3}, \mathrm{SF}_{(\mathrm{N} 1+\mathrm{N} 2) / 2}$ is the mean value of stem sap flow for $\mathrm{N}_{1}$ and $\mathrm{N}_{2}, \mathrm{SPAD}_{\mathrm{i}}$ is leaf SPAD for $\mathrm{N}_{3}, \mathrm{SAPD}_{(\mathrm{N} 1+\mathrm{N} 2) / 2}$ is the mean value of leaf SPAD for $\mathrm{N}_{1}$ and $\mathrm{N}_{2}$ ].

RELATIONSHIP BETWEEN DAILY STEM SAP FLOW AND METEOROLOGICAL FACTORS AND ET $_{\mathbf{0}}$. Figures 5 and 6 show linear relationships between daily stem sap flow and meteorological factors as well as $\mathrm{ET}_{0}$ under different water and $\mathrm{N}$ treatments. The relationships between measured daily stem sap flow and daily $\mathrm{R}_{\mathrm{s}}, \mathrm{T}_{\mathrm{a}}, \mathrm{VPD}$, and $\mathrm{ET}_{0}$ were very significant $(P<0.001)$ for all water treatments (Fig. 5A-D), whereas the slopes of the linear regression were the highest in $T_{1}$ followed by $\mathrm{T}_{2}$ and $\mathrm{T}_{3}$. All the differences of slopes between $\mathrm{T}_{1}$ and $\mathrm{T}_{3}$ were significant.

The measured daily stem sap flow was significantly $(P<0.001)$ and positively correlated with $\mathrm{R}_{\mathrm{s}}, \mathrm{T}_{\mathrm{a}}, \mathrm{VPD}$, and $\mathrm{ET}_{0}$ for all $\mathrm{N}$ treatments (Fig. 6A-D), but the slopes of the regressions were not significantly different among $\mathrm{N}$ treatments. The coefficients of determination for the $\mathrm{N}$ experiment in the 2012 season were lower than that for the water experiment in the 2010-11 season, which to some extent was attributed to the partial shade around noon by the straw mats.

LEAF STOMATAL CONDUCTANCE UNDER DIFFERENT WATER AND N TREATMENTs. The diurnal variations of leaf $g_{\mathrm{S}}$ on $23 \mathrm{Apr}$. 2011 had a similar trend for all water treatments except for the $1500 \mathrm{HR}$ reading in $\mathrm{T}_{3}$ (Fig. 7A). The $g_{\mathrm{S}}$ values were lower in the morning and evening and higher around noon. They decreased with the decrease of soil available water (Fig. 8). At $1300 \mathrm{HR}$, the $g_{\mathrm{S}}$ values were $10 \%$ and $31 \%$, respectively, lower in $\mathrm{T}_{2}$ and $\mathrm{T}_{3}$ than in $\mathrm{T}_{1}$.

In the $\mathrm{N}$ treatments, there was a slight midday depression in $g_{\mathrm{S}}$ because of irrigation (two-thirds of sufficient water supply) after 12 DAT (Fig. 7B). There were no significant differences for $g_{\mathrm{S}}$ among the $\mathrm{N}$ treatments at each time.

LEAF SPAD AND LAI UNDER DIFFERENT AND N TREATMENTS. Figure 9A shows that, most of the time, leaf SPAD in $\mathrm{N}_{1}$ was close to that in $\mathrm{N}_{2}$, but they were both significantly higher than that in $\mathrm{N}_{3}$. Leaf area index had a similar trend (Fig. 9B) as the SPAD reading among the $\mathrm{N}$ treatments. No significant differences were observed in LAI among the $\mathrm{N}$ treatments on 2 May 2012 and 5 July 2012.

\section{Discussion}

In this study, a pronounced reduction in stem sap flow was observed in response to water deficits (Figs. 2A and 3A), especially for $\mathrm{T}_{3}$ (half of the sufficient water supply), which was
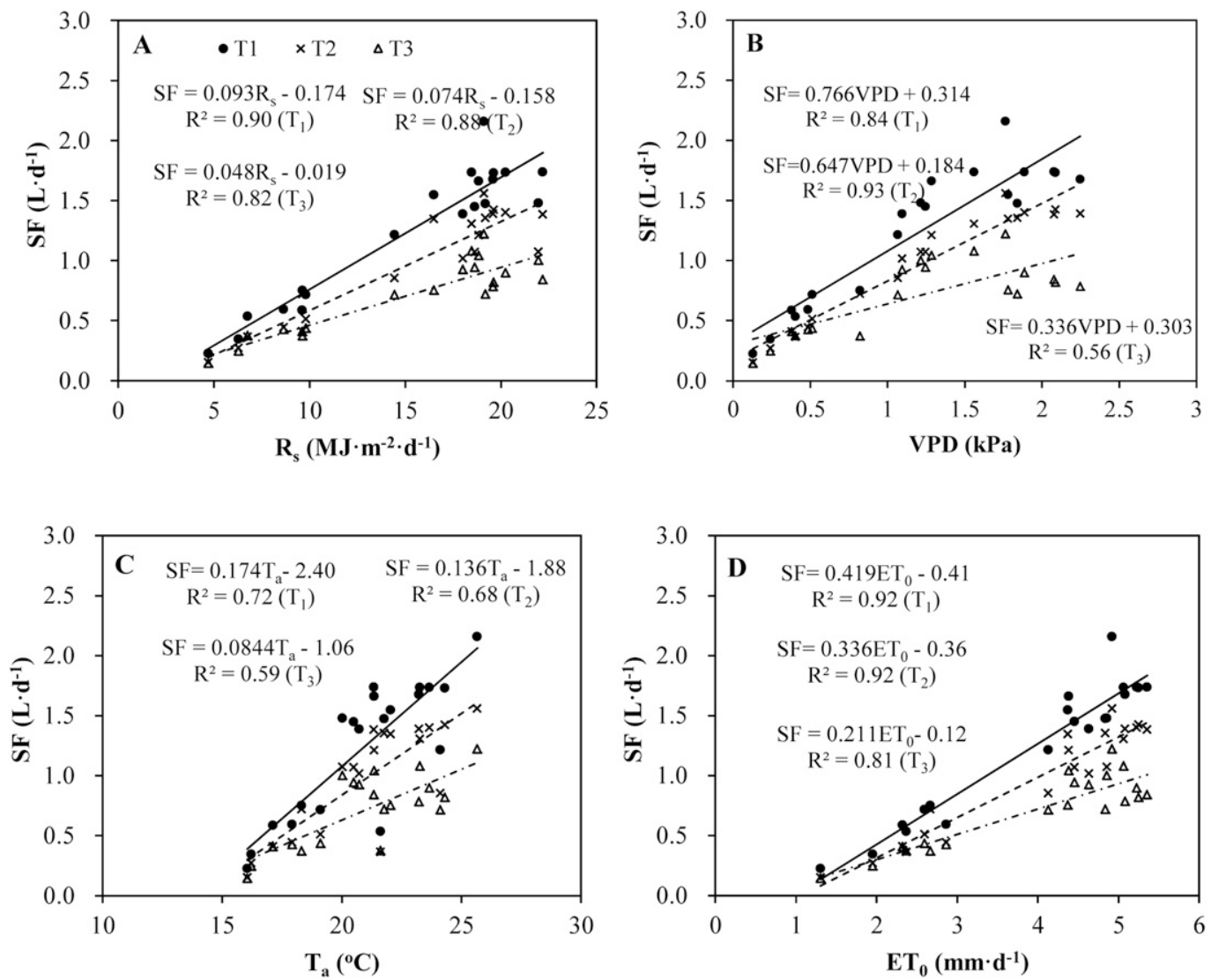

Fig. 5. Relationship between daily stem sap flow (SF) of tomato and (A) daily solar radiation $\left(\mathrm{R}_{\mathrm{s}}\right),(\mathbf{B})$ vapor pressure deficit $(\mathrm{VPD}),(\mathbf{C})$ air temperature $\left(\mathrm{T}_{\mathrm{a}}\right)$, and (D) reference evapotranspiration ( $\left.E T_{0}\right)$ under different water treatments. $T_{1}, T_{2}$, and $T_{3}$ are sufficient water supply, two-thirds $T_{1}$, and half $T_{1}$, respectively, under a typical nitrogen $(\mathrm{N})$ application rate; i.e., $57.4 \mathrm{~g} \cdot \mathrm{m}^{-2} \mathrm{~N}$. 

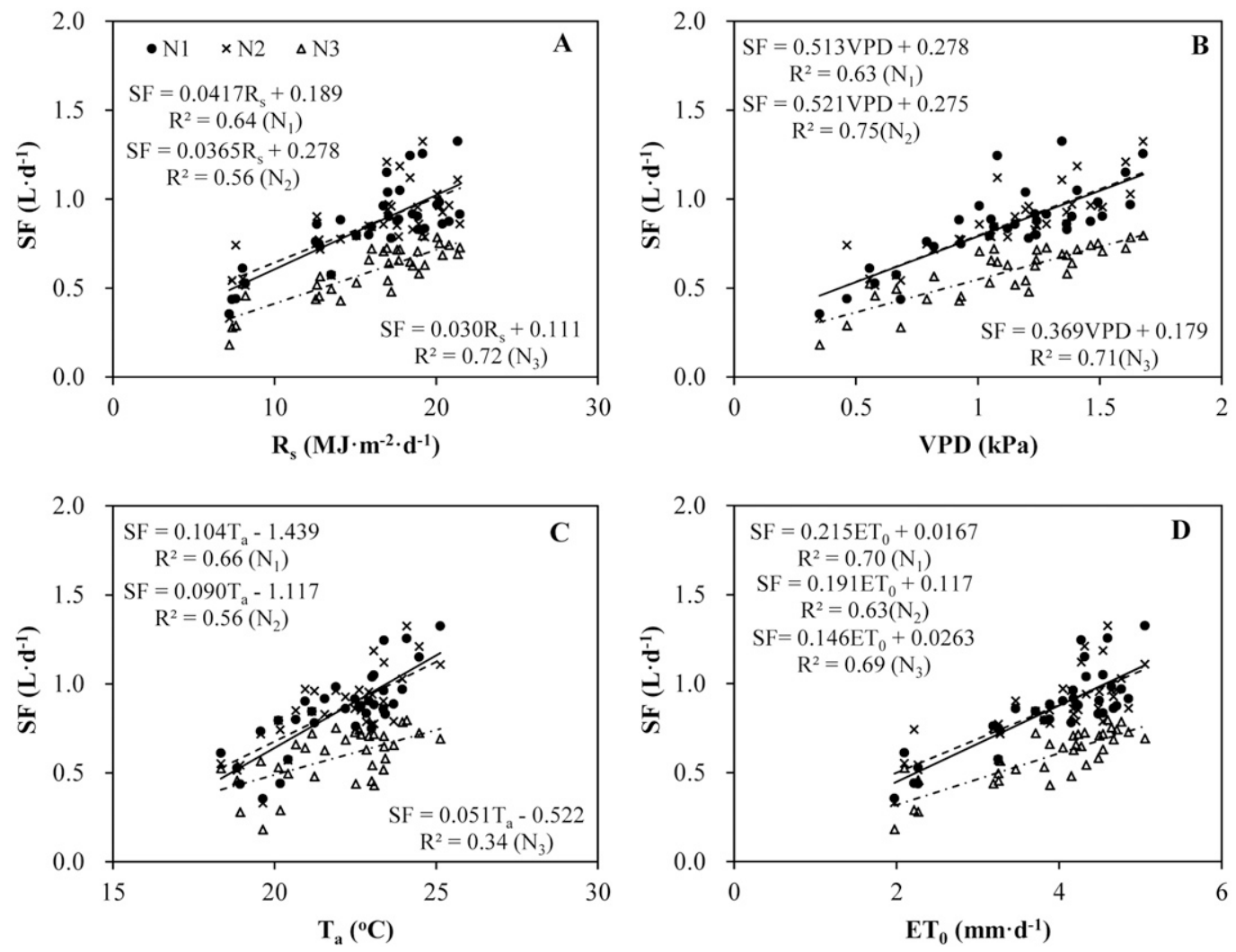

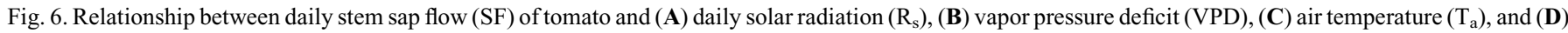
reference evapotranspiration $\left(\mathrm{ET}_{0}\right)$ under different nitrogen $(\mathrm{N})$ treatments. $\mathrm{N}_{1}, \mathrm{~N}_{2}$, and $\mathrm{N}_{3}$ are typical $\mathrm{N}$ application rate; i.e., 57.4 g. $\mathrm{m}^{-2} \mathrm{~N}$, two-thirds $\mathrm{N}_{1}$, and half $\mathrm{N}_{1}$, respectively, under $2 / 3$ sufficient water supply.

most evident when potential $\mathrm{ET}_{0}$ was high (Fig. 5D). A reduction in sap flow that was observed for tomato 2 or $3 \mathrm{~d}$ after water stress was imposed became more significant over time (Grey, 2010; Vermeulen et al., 2007). Yang et al. (2012) also reported that on a sunny day, sap flow of tomato for severe water stress treatment $\left(30 \%\right.$ to $\left.40 \% \theta_{\mathrm{F}}\right)$ was only $25.8 \%$ of that for normal water treatment $\left(70 \%\right.$ to $\left.80 \% \theta_{\mathrm{F}}\right)$. Stomatal closure is generally the dominant mechanism for transpiration reduction as water stress develops (Hsiao, 1973), but transpiration decreases in response to water stress even when stomata are open if the water stress is a result of limited availability of water in the root zone as opposed to a large atmospheric demand for water (Grey, 2010).

When soil is subjected to drought, leaf stomata may reduce their opening to decrease water loss through transpiration (Davies and Zhang, 1991; Xiao and Wang, 2004). Many studies show that leaf $g_{S}$ is reduced under water deficit treatment (Grey, 2010; Torrecillas et al., 1995; Vermeulen et al., 2007), which was also observed on a sunny day in this study (Fig. 7A). The relative daily stem sap flow increased rapidly with the increase of REW up to a threshold of 0.57 and increased slowly thereafter. This trend is different from the study of a pearjujube tree grown under greenhouse conditions, which showed a linear relationship between relative daily stem sap flow and REW (Ma et al., 2007). The relationship from our study suggests that a signal from the roots may be transported to the shoots to lower the $g_{\mathrm{S}}$ and water loss from transpiration before a significant shoot water deficit takes place when roots experience drought stress (Davies and Zhang, 1991). This mechanism of drought response can help plants prolong their lives with limited water supply.

On sunny days, as a result of high potential $\mathrm{ET}_{0}$, transpiration was high. However, water deficits restrict root water uptake, which in turn lower stem sap flow. Thus, big differences in stem sap flow among the water treatments were observed (Fig. 2B). On cloudy or rainy days, root water uptake meets the low potential $\mathrm{ET}_{0}$ and soil water content did not significantly affect stem sap flow; thus, the differences in sap flow among the water treatments were small.

Leaf chlorophyll content is closely related to leaf $\mathrm{N}$ content in tomato (Sandoval Villa et al., 2000). When plants suffer N deficit, leaf SPAD is low. However, leaf SPAD can also be low when $\mathrm{N}$ content is excessively high ( $\mathrm{Li}$ et al., 2010). Leaf SPAD and LAI were similar in $\mathrm{N}_{1}$ to that in $\mathrm{N}_{2}$, but they were both significantly higher than that in $\mathrm{N}_{3}$ (Fig. 9), which reflects that plants in $\mathrm{N}_{3}$ may suffer $\mathrm{N}$ stress and suggest that plants in $\mathrm{N}_{1}$ may receive excess.

The stem sap flow rates in $\mathrm{N}_{1}$ and $\mathrm{N}_{2}$ plants were similar, but a decline of stem sap flow was observed on $4 \mathrm{~d}$ in $\mathrm{N}_{3}$ plants under two-thirds sufficient water supply (Fig. 3B). A linear $(P<$ $0.05)$ relationship between the $\mathrm{SF}_{\mathrm{i}} / \mathrm{SF}_{(\mathrm{N} 1+\mathrm{N} 2) / 2}$ and $\mathrm{SPAD}_{\mathrm{i}} /$ $\mathrm{SPAD}_{(\mathrm{N} 1+\mathrm{N} 2) / 2}$ suggests that $\mathrm{N}$ deficit may affect water loss from transpiration. Although a previous study showed that $\mathrm{N}$ deficit decreased $g_{\mathrm{S}}$ (Chapin et al., 1988), $g_{\mathrm{S}}$ among the $\mathrm{N}$ treatments under a water deficit condition was not significantly different in our study (Fig. 7B). The lower LAI (Fig. 9B) in $\mathrm{N}_{3}$ may contribute to the difference because transpiration is usually directly related to LAI. 

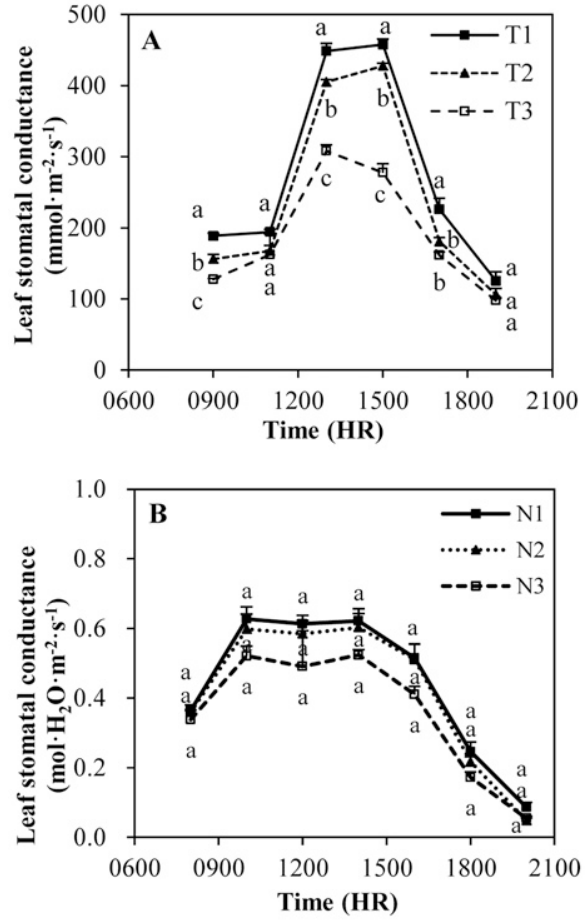

Fig. 7. Diurnal variation of leaf stomatal conductance $\left(g_{\mathrm{S}}\right)$ of tomato under $(\mathbf{A})$ different water treatments on 23 Apr. 2011 and (B) different nitrogen $(\mathrm{N})$ treatments on 29 May 2012. Error bars indicate SE. Mean values at each time point followed by different letters (a-c) are significantly different at the $P_{0.05}$ level. $T_{1}, T_{2}$, and $T_{3}$ are sufficient water supply, two-thirds $T_{1}$, and half $T_{1}$, respectively, under a typical $\mathrm{N}$ application rate $\left(\mathrm{N}_{1}\right)$; i.e., $57.4 \mathrm{~g} \cdot \mathrm{m}^{-2} \mathrm{~N} . \mathrm{N}_{2}$ and $\mathrm{N}_{3}$ are two-thirds $\mathrm{N}_{1}$ and half $\mathrm{N}_{1}$, respectively, under $\mathrm{T}_{2}$.

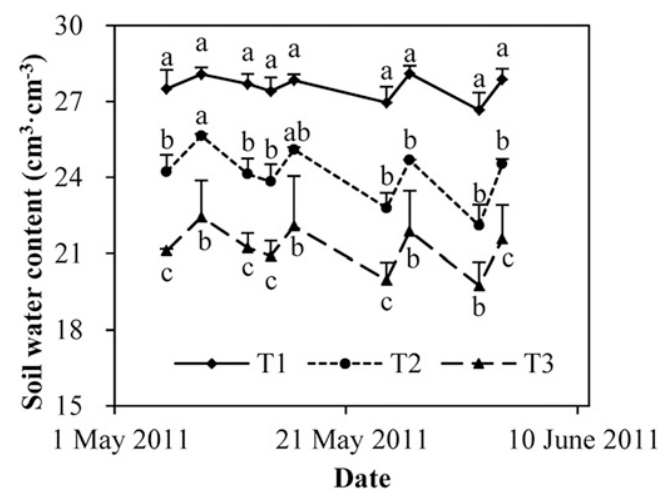

Fig. 8. Dynamics of soil water content of tomato for different water treatment $(\mathrm{n}=$ three replications). Mean values at each time point followed by different letters (a-c) are significantly different at the $P_{0.05}$ level. $\mathrm{T}_{1}, \mathrm{~T}_{2}$, and $\mathrm{T}_{3}$ are sufficient water supply, two-thirds $\mathrm{T}_{1}$, and half $\mathrm{T}_{1}$, respectively, under a typical nitrogen $(\mathrm{N})$ application rate (i.e., $57.4 \mathrm{~g} \cdot \mathrm{m}^{-2} \mathrm{~N}$ ).

Nighttime sap flow of tomato accounted for $5.7 \%$ to $8.5 \%$ of total daily sap flow, which could be attributed to rehydration and/or transpiration (Caird et al., 2007b). Nighttime transpiration has been found in many $\mathrm{C}_{3}$ and $\mathrm{C}_{4}$ species (Caird et al., 2007a, 2007b; Medrano et al., 2005; Seginer et al., 1990; Snyder et al., 2003; Yoo et al., 2009). Caird et al. (2007b) showed that the nighttime water loss in field-grown tomato measured by a lysimeter was $3.0 \%$ to $10.8 \%$ of the total daily water loss, and nighttime water loss for plants in the greenhouse could account for as much as $7.4 \%$ to $24.8 \%$ of the daily water loss. Jolliet and Bailey (1992) also observed that nighttime water

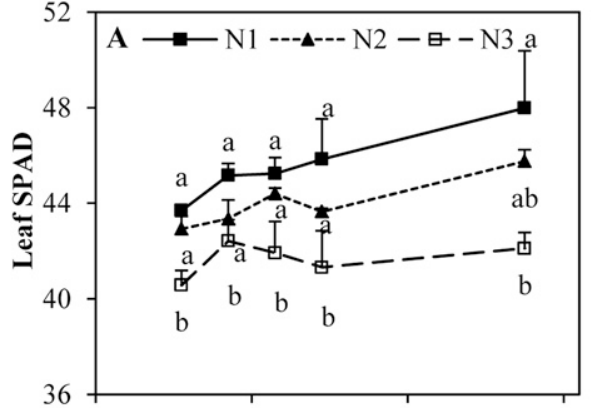

29 May 20128 June 201218 June 201228 June 2012 Date

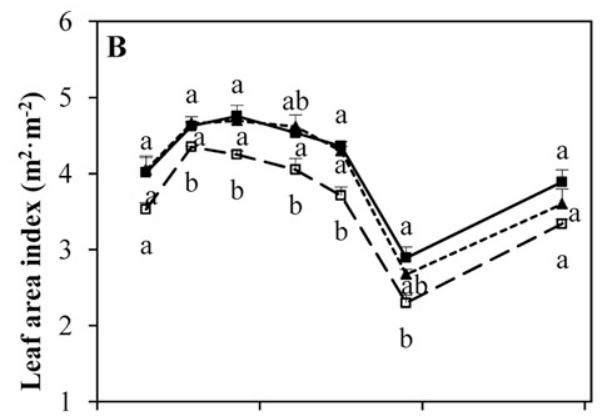

25 Apr. 201220 May 201214 June 20129 July 2012

Date

Fig. 9. Evolution of (A) leaf chlorophyll content (SPAD) and (B) leaf area index of tomato under different nitrogen $(\mathrm{N})$ treatments. Error bars indicate SE. Mean values at each time point followed by different letters $(\mathrm{a}-\mathrm{c})$ are significantly different at the $P_{0.05}$ level. $\mathrm{N}_{1}, \mathrm{~N}_{2}$, and $\mathrm{N}_{3}$ are typical $\mathrm{N}$ application rate (i.e., $57.4 \mathrm{~g} \cdot \mathrm{m}^{-2} \mathrm{~N}$ ), two-thirds $\mathrm{N}_{1}$, and half $\mathrm{N}_{1}$, respectively, under two-thirds sufficient water supply.

use was $9 \%$ to $22 \%$ of the total daily water use for greenhousegrown tomato. Several studies suggested that nighttime water loss is primarily the result of incomplete stomatal closure at night (Caird et al., 2007b; Easlon and Richards, 2009; Snyder et al., 2003). In our study, significant correlations $(P<0.05)$ between nighttime sap flow and VPD were found for all treatments, especially for different water treatments (Fig. 4A and B), suggested that the stomata of tomato plants experienced incomplete closure and transpiration occurred at night.

\section{Concluding Remarks}

In this study, daily stem sap flow of tomato decreased when water deficit was imposed at fruit set and harvest stages (after 89 DAT). The average daily stem sap flow was $22.1 \%$ and $42.8 \%$ of that in sufficiently watered plants $\left(\mathrm{T}_{1}\right)$, for the twothirds $\left(\mathrm{T}_{2}\right)$, and half $\left(\mathrm{T}_{3}\right)$ water treatments, respectively, during the measurement period. Stem sap flow, $g_{\mathrm{S}}$, and LAI all decreased when the typical $\mathrm{N}$ application rate was reduced to half, but not when reduced to two-thirds.

Nighttime stem sap flow accounted for a significant proportion of the total daily stem sap flow under different water and $\mathrm{N}$ treatments, which might lower the crop water productivity. The magnitude of this effect is great enough to deserve further study, especially in regard to its physiological and ecological relevance. As a result of the limitation of the instruments, this research did not study the interaction between water and $\mathrm{N}$ under sufficient water supply and half of the sufficient water supply, but it also warrants further study. 


\section{Literature Cited}

Caird, M.A., J.H. Richards, and L.A. Donovan. 2007a. Nighttime stomatal conductance and transpiration in $\mathrm{C}_{3}$ and $\mathrm{C}_{4}$ plants. Plant Physiol. 143:4-10.

Caird, M.A., J.H. Richards, and T.C. Hsiao. 2007b. Significant transpirational water loss occurs throughout the night in field-grown tomato. Funct. Plant Biol. 34:172-177.

Chapin, F.S., C.H. Walter, and D.T. Clarkson. 1988. Growth response of barley and tomato to nitrogen stress and its control by abscisic acid, water relations and photosynthesis. Planta 173:352-366.

Claussen, W. 2002. Growth, water use efficiency, and proline content of hydroponically grown tomato plants as affected by nitrogen source and nutrient concentration. Plant Soil 247:199-209.

Davies, W.J. and J. Zhang. 1991. Root signals and the regulation of growth and development of plants in drying soil. Annu. Rev. Plant Biol. 42:55-76.

Easlon, H.M. and J.H. Richards. 2009. Drought response in selfcompatible species of tomato (Solanaceae). Amer. J. Bot. 96:605611.

Fernández, J.E., M.J. Palomo, A. Diaz-Espejo, B.E. Clothier, S.R. Green, I.F. Girón, and F. Moreno. 2001. Heat-pulse measurements of sap flow in olives for automating irrigation: Tests, root flow and diagnostics of water stress. Agr. Water Mgt. 51:99-123.

Fernández, M.D., S. Bonachela, F. Orgaz, R. Thompson, J.C. López, M.R. Granados, M. Gallardo, and E. Fereres. 2010. Measurement and estimation of plastic greenhouse reference evapotranspiration in a Mediterranean climate. Irrig. Sci. 28:497-509.

Fernández, M.D., S. Bonachela, F. Orgaz, R.B. Thompson, J.C. López, M.R. Granados, M. Gallardo, and E. Fereres. 2011. Erratum to: Measurement and estimation of plastic greenhouse reference evapotranspiration in a Mediterranean climate. Irrig. Sci. 29:91-92.

Gong, D.Z., J.P. Wang, S.Z. Kang, X.T. Xu, F.C. Zhang, and Z.J. Li. 2001. Variation of root and trunk sap flow rate under different soil water wetting patterns. Trans. Chinese Soc. Agr. Eng. 17:34-38.

Grey, S.N. 2010. Monitoring the simultaneous response of various water status indicators for use in the irrigation scheduling and drought stress detection of a greenhouse tomato crop. Master's diss., Univ. Zimbabwe, Harare, Zimbabwe.

Guak, S., D. Neilsen, P. Millard, R. Wendler, and G.H. Neilsen. 2003. Determining the role of $\mathrm{N}$ remobilization for growth of apple (Malus domestica) trees by measuring xylem-sap N flux. J. Expt. Bot. 54:2121-2131.

Guérin, V., L. Huché-Thélier, and S. Charpentier. 2007. Mobilisation of nutrients and transport via the xylem sap in a shrub (Ligustrum ovalifolium) during spring growth: $\mathrm{N}$ and $\mathrm{C}$ compounds and interactions. J. Plant Physiol. 164:562-573.

Hsiao, T.C. 1973. Plant responses to water stress. Annu. Rev. Plant Physiol. 24:519-570.

Jolliet, O. and B.J. Bailey. 1992. The effect of climate on tomato transpiration in greenhouses: Measurements and models comparison. Agr. For. Meteorol. 58:43-62.

Li, L.Z., R. Guo, H.P. Li, and Y. Cao. 2010. Effects of nitrogen concentration in hydroponics on growth and development of tomato and spectral characteristics of leaf in greenhouse. Plant Nutr. Fert. Sci. 16:965-969.

Ma, F.S., S.Z. Kang, F.S. Li, J.H. Zhang, T.S. Du, X.T. Hu, and M.X. Wang. 2007. Effect of water deficit in different growth stages on stem sap flux of greenhouse grown pear-jujube tree. Agr. Water Mgt. 90:190-196.

Medrano, E., P. Lorenzo, M.C. Sánchez-Guerrero, and J.I. Montero. 2005. Evaluation and modelling of greenhouse cucumber-crop transpiration under high and low radiation conditions. Sci. Hort. 105:163-175.

Ortuño, M.F., J.J. Alarcón, E. Nicolás, and A. Torrecillas. 2005. Sap flow and trunk diameter fluctuations of young lemon trees under water stress and rewatering. Environ. Expt. Bot. 54:155-162.

Ortuño, M.F., Y. García-Orellana, W. Conejero, M.C. Ruiz-Sánchez, J.J. Alarcón, and A. Torrecillas. 2006. Stem and leaf water potentials, gas exchange, sap flow, and trunk diameter fluctuations for detecting water stress in lemon trees. Trees (Berl.) 20:1-8.

Qiu, R.J., S.Z. Kang, F.S. Li, T.S. Du, L. Tong, F. Wang, R.Q. Chen, J.Q. Liu, and S.E. Li. 2011. Energy partitioning and evapotranspiration of hot pepper grown in greenhouse with furrow and drip irrigation methods. Sci. Hort. 129:790-797.

Qiu, R.J., J.J. Song, T.S. Du, S.Z. Kang, L. Tong, R.Q. Chen, and L.S. $\mathrm{Wu}$. 2013. Response of evapotranspiration and yield to planting density of solar greenhouse grown tomato in northwest China. Agr. Water Mgt. 130:44-51.

Sandoval Villa, M., E.A. Guertal, and C.W. Wood. 2000. Tomato leaf chlorophyll meter readings as affected by variety, nitrogen form, and nighttime nutrient solution strength. J. Plant Nutr. 23:649-661.

Seginer, I., D. Kantz, N. Levav, and U.M. Peiper. 1990. Night-time transpiration in greenhouses. Sci. Hort. 41:265-276.

Snyder, K.A., J.H. Richards, and L.A. Donovan. 2003. Night-time conductance in $\mathrm{C}_{3}$ and $\mathrm{C}_{4}$ species: Do plants lose water at night? J. Expt. Bot. 54:861-865.

Tognetti, R., R. D’Andria, G. Morelli, D. Calandrelli, and F. Fragnito. 2004. Irrigation effects on daily and seasonal variations of trunk sap flow and leaf water relations in olive trees. Plant Soil 263:249-264.

Torrecillas, A., C. Guillaume, J.J. Alarcón, and M.C. Ruiz-Sánchez. 1995. Water relations of two tomato species under water stress and recovery. Plant Sci. 105:169-176.

Trambouze, W. and M. Voltz. 2001. Measurement and modelling of the transpiration of a Mediterranean vineyard. Agr. For. Meteorol. 107:153-166.

Vermeulen, K., K. Steppe, N.S. Linh, R. Lemeur, L. De Backer, P. Bleyaert, J. Dekock, J.M. Aerts, and D. Berckmans. 2007. Simultaneous response of stem diameter, sap flow rate and leaf temperature of tomato plants to drought stress. Intl. Symp. High Tech. Greenhouse System Mgt. 801:1259-1266.

Xiao, L. and S. Wang. 2004. Plant physiology. China Agr. Sci. Technol. Press, Beijing, China.

Yang, Z.Q., H.T. Zhang, Y.X. Li, X.D. Peng, Z.L. Zhou, K. Zhu, and X. Zhao. 2012. Response of sap flow and leaf water potential for greenhouse tomato under moisture stress. Chinese J. Agrometeorol. 33:382-387.

Yoo, C.Y., H.E. Pence, P.M. Hasegawa, and M.V. Mickelbart. 2009. Regulation of transpiration to improve crop water use. Crit. Rev. Plant Sci. 28:410-431.

Zhang, Z.L., F.C. Zhang, C.X. Zheng, and F.Q. Ni. 2009. Study on variation law of sap flow of peach seedling under different water and nitrogen conditions. Water Saving Irr. 2:1-4. 